\title{
Russia and Other Significant Others in Latvian Caricatures
}

\section{Lidia S. Zhirnova}

Moscow State Institute of International Relations. Moscow, Russia.

Email: l.zhirnova[at]inno.mgimo.ru

\section{Abstract}

After the collapse of the Soviet Union Latvia faced the need to redefine its national identity in a new international environment. Its elite took a clear Euro-Atlantic course, and the image of Latvia in the public space has been largely defined in contrast to the image of Russia ever since. One of the ways to understand how Latvia sees itself and Russia is analyzing political cartoons. The purpose of the study is to bring out the attributes of Russia as a significant Other in caricatures in national newspapers and analyze how they correspond to the characteristics of Latvia, thus defining the outlines of the mental border between the two. The analysis shows two main sets of ideas associated with Russia in Latvian cartoons: one is power, threat and aggression, and the other is propaganda and lies. Although the genre of caricature is meant to be disrespectful, the comparison with cartoons featuring the EU shows that the cartoonists are much more hostile towards Russia. Latvia has succeeded in distancing itself from Russia mentally and uses its image as an antagonist Other, however the cartoons show lack of national pride and doubt that the country has become a rightful member of the Western world.

\section{Keywords}

National Identity; Cartoons; Caricature; Latvia; Russia; European Union; Other; Stereotypes; Mental Border; Constructivism 


\section{Россия и другие значимые Другие в латышских карикатурах}

\section{Жирнова Лидия Сергеевна}

Московский государственный институт международных отношений. Москва, Россия. Email: l.zhirnova[at]inno.mgimo.ru

\section{Аннотация}

После распада Советского Союза Латвия встала перед необходимостью заново определить свою национально-государственную идентичность в новой международной обстановке. Ее элита взяла четкий евроатлантический курс, и с тех пор образ Латвии в публичном пространстве зачастую формируется через противопоставление России. Один из способов определить, как Латвия видит себя и Россию, - это проанализировать политические карикатуры. Цель исследования - выделить атрибуты России как значимого Другого в карикатурах общенациональных изданий и проанализировать, как они соотносятся с характеристиками Латвии, тем самым очертив ментальную границу между двумя странами. Анализ показывает два главных набора идей, которые ассоциируются с Россией в латышских карикатурах: во-первых, это сила, угроза и агрессия, во-вторых, это ложь и пропаганда. Хотя жанр карикатуры неотъемлемо связан с идеей неуважения, сравнение с карикатурами, изображающими ЕС, показывает, что их авторы намного более враждебны к России. Латвия смогла ментально дистанцироваться от России и использует ее образ как образ антагонистического Другого. Однако карикатуры демонстрируют недостаток национальной гордости и сомнение в том, что Латвия действительно стала полноправным членом западного мира.

\section{Ключевые слова}

национальная идентичность; шарж; карикатуры; Латвия; Россия; Европейский Союз; Другой; стереотипы; ментальная граница; конструктивизм

Это произведение доступно по лицензии Creative Commons «Attribution» («Атрибуция») 4.0 Всемирная 


\section{Introduction}

The collapse of the Soviet Union in 1991 created not only new state borders, but also the need for the former Soviet republics to redefine their national identity in a new international environment. Latvia was one of the states faced with this challenge. Its new elite set a clear Euro-Atlantic course, and the formation of national identity was based on comparing Latvia to other geopolitical entities. Central to these attempts to redefine Latvia was the need to distance itself from Russia and emphasize the differences between the two countries. In case of Latvia these attempts were complicated by close historical, cultural and economic ties with Russia as well as a large Russian-speaking minority.

It took around 26 years to agree upon, demarcate and delimit the physical border between Latvia and Russia - final documents on this matter were signed only in October 2017 (Latvia and Russia sign final documents..., 2017). The mental border as well as Latvian identity are defined and redefined up to the present day; Russia remains one of the main significant Others for Latvia and the distancing from it goes on.

One of the ways to capture and study this process is analyzing newspaper cartoons. Caricatures thrive on national stereotypes and strengthen them. They help to understand cognitive metaphors related to various objects. Their advantages as a means of transferring attitudes and views are fast distribution and comprehensibility, sometimes even to those who do not know the language of the author. However, it is usually difficult to perceive the intentions of the author completely without certain linguistic and logical presuppositions and knowledge of political context (Dugalich, 2020, p.481).

Latvia especially fits this study as it runs a long-standing tradition of printed caricatures on topical issues. This kind of materials appears in Latvian newspapers every day. This research focuses on the cartoons of four Latvian national newspapers: Latvijas Avizze, Neatkarīgā Rìta Avizze, Diena and Dienas Bizness. The caricatures were gathered over two months of 2016: March and May.

The aim of the study is to bring out the attributes of Russia as a significant Other in caricatures and analyze how they correspond to those of Latvia, thus defining the outlines of the mental border between the two. The interim step is comparing Russia's image to other significant Others, first and foremost the European Union.

The topicality of the research lies not only in clarifying Russia's image in a neighbouring country with a large Russian-speaking population, which is important taking into account Russian policy of supporting its compatriots abroad, but also more broadly in deepening knowledge of the mechanisms of shaping national identity. 


\section{Literature review}

The studies of cartoons and the way countries are depicted in them are widespread, especially in historical context. However, Latvia has not often become an object of such research.

One of the researchers who closely study history and present of Latvian caricatures is Gundega Gailite from the Latvian Academy of Arts. One of the main focuses of her articles is the way caricatures helped to forge Latvian national identity in the end of the 19th and the beginning of the 20th century. Gailite shows that in that period artists actively employed satirical graphics to deform images and represent Self and Other (2012a, p. 45). In another article (2013a) she reveals the role of the image of "Mother Latvia", which is central to the Latvian identity.

A number of her works consider the representation of Russia in Latvian caricatures in the context of the relations of the two countries (2011) with the special emphasis on the image of "The Russian Bear" (2012b, 2013b). Gailite, as well as Procevska (2011), proves that image of Russia is widely spread in Latvian media both in Latvian and in Russian. According to Gailite, although in the traditional Latvian culture bear is seen as a predominantly positive image (with a wide-spread notion of a "Laimes lācis" - "The Bear of Luck" - an equivalent of a bluebird of happiness and national folk hero Lāčplēsis with ursine ears, the son of a bear and a woman, who, however, got his name from tearing a bear apart), modern cartoon artists use the image of a bear to emphasize the negative traits of Russia.

Therefore in Latvia the European tradition of depicting Russia as a Bear in a predominantly negative sense has established partially despite the local cultural context. According to Denis Khrustalev (2011, p. 137), the first graphic works depicting Russia as a bear appeared in England as early as 1737-1740 and over the centuries have became omnipresent. As Sergey Troicky (2020, p. 160) argues, such a representation manifests the need to depict a country - in this case Russia not just as an Other, but as an Alien - a beast, exaggerating national stereotypes. Other countries also had their equivalent beasts on the mental map, for example, the USA was depicted as a bald eagle, Germany as an eagle, France as a cock, China as a dragon. As Baratay (2003) notes, the animalization of an adversary may strengthen in times of tensions inside and outside the society.

A number of authors focus on the mechanics of cartoons. As Salamanca and Rodriguez (2015) state, a caricature is based not on all the characteristics of an object, but on one or two most distinctive features, thus simplifying and brightening the image. In this sense cartoon images are close to the way national stereotypes are formed (Popkov, 181). Caricature employs exaggeration, infantilising and physiognomic stereotyping to hyperbolise the traits that have been singled out (Moloney, Holtz \& Wagner, 2013).

William A. Gamson and David Stuart (1992, p. 61-62) also point out a special place of cartoonists in editorial stuff: although they are not completely autonomous, they are licensed to heckle and be irreverent. Another aspect of humour that makes 
cartoons invaluable for analysing national identity is its function of a "safe house" where socio-cultural and political allergens can safely be brought to the fore (Heidari-Shahreza, 2021). However, it is important to keep in mind that humour "does not resolve tensions, but sustains them" (Tavory, 2014). Moreover, that is exactly the tension that makes a joke funny: if the tension goes away, so does the laughter.

As it is shown in the collection "Images of the Other in Ethnic Caricatures of Central and Eastern Europe" (2010), cartoons are an efficient means of creating and spreading national stereotypes as a crucial element of the national identity. It is vital to point out that in case of a forming identity there is no stable and consistent set of ideas transferred through cartoons - instead they become a site of struggle over construction of social reality (Gurevitch \& Levy, 1985, p. 19). Political cartoons can also play a role in agenda-setting, channelling public attention to certain issues that need to be discussed (Alkazemi \& Wanta, 2015).

An important aspect here is a powerful emotional component cartoons contain. As Simon Koschut (2018, p. 495) points out, status differentiation "is rooted in collective emotions that undergird and reproduce social discourses and identities". Despite its importance this emotional aspect is often overlooked, but in case of cartoons it is impossible to ignore.

The concept of the Other was brought to political studies from sociology, namely, from symbolic interactionism which studies the role of significant Others in the definition of the self. A brief overview of this theory helps to grasp the main cognitive metaphors behind the concept of the significant Other. Mead (1965 [1934], p.204) viewed "me" as created by social relationships and reflecting the attitudes of others. As Berger and Luckmann (1966, p. 170) state, the development of the self is based on "a dialectic between identification by others and self-identification". In this concept significant Others play a crucial role in self-definition and reality maintenance, they are important "for ongoing confirmation of that crucial element of reality we call identity". The researchers name significant Others as "principal agents" with "less significant others" serving "as a sort of chorus" (Berger \& Luckman, 1966, p. 170). Symbolic interactionists focus not on objective structures, but on subjective meaning created in the process of interaction with Others. Lately these ideas were developed not only in self and identity studies, but also in the fields of cultural studies, gender and status studies, research of collective behaviour and social movements as well as social context and the environment (Carter \& Fuller, 2016).

The question why there is a need for the Other and how it influences national identity is a point of interest for cultural and political geography. As Eriksen states, group identity is based not only on inner concord and shared culture, but also on opposing others. The author thus singles out two regimes of identification - one based on we-hood and the other on us-hood formed on countering an external agent that can be a real or an imaginary adversary (Eriksen, 1995, p. 427). Although a variety of identities may exist, usually one, most prevailing comes 
to the forefront. That is especially true for Latvia where the need to distance oneself from Russia is inseparable from the inner cleavage between the Latvian and the Russian-speaking population. Although ethnic minorities are numerous, almost all of them are Russian-speaking and are referred to simply as Russians in the public discourse.

One of the issues in the scope of attention of researchers is whether collective identity can be formed without the Other. The discussion on this matter continues. One point of view is that the relations with the Other need to be confrontational (Schmitt, 1996). Other researchers believe that there is no need for an antagonistic Other in the process of forging a collective identity (Abizadeh, 2005, p. 45). Abizadeh states that the definition of the Other is always unclear and fluid, but when the Other is defined on a map as a region or a country, part of this vagueness goes away.

Johnson and Coleman (2012, p. 110) show that in forging national identity an internal Other can be as important as an external. That is especially true for Latvia: the internal Other in this country - Russian-speaking population is as important for the identity discourse as the external Other - Russia. These two Others form a close community - Russians are often depicted as a malicious fifth column of Russia unable to integrate into Latvian society and not particularly eager to do it. Spatially the internal Other is represented as the region of Latgale bordering on Russia and Belarus as well as Riga where the Russian-speaking population prevails.

\section{Methodology}

The study is based on the cartoons from all four national daily newspapers in Latvian: Latvijas Avīze, Neatkarīgā Rìta Avīze, Diena and Dienas Bizness. The fifth national daily newspaper Vesti Segodnya (since 2017 - Segodnya) is printed in Russian and is not included in the study, because it mostly represents the discourse of the internal Other - the Russian-speaking community; besides, it does not print caricatures as regularly as other four newspapers.

Basic understanding of the core audience of each newspaper is necessary to interpret cartoons more adequately. Latvijas Avize ("The Latvian Newspaper") uses caricatures most frequently printing from one to four cartoons in each issue. It is a national conservative daily newspaper with a variety of supplements. Its target audience are Latvians, mostly in the countryside, who believe in the ideal of a "Latvian Latvia" and are most suspicious of the large Russian-speaking minority and the plans of Russia concerning Latvia. However, the paper does not favour deep European integration either, pointing out the dangers of losing national identity and traditional values.

Diena ("The Day") is a mainstream newspaper with the largest number of subscribers. For a long time, it was considered a paper of bureaucracy. It prints one cartoon in each issue. 
Dienas Bizness ("The Business of the Day") targets businessmen and those who are interested in the economic agenda. Following the example of the Financial Times, Dienas Bizness is printed on pink paper. The cartoons are published daily and accompany the editorial. The paper represents a more pragmatic view of Russia as a traditional trade partner.

Neatkarigā Rìta Avize ("The Independent Morning Newspaper") is a newspaper with a rich history that is traced back to the paper of the Latvian Social Democratic Workers' Party called Cina ("The Struggle") that was first published in 1904. Nowadays it can be characterized as a newspaper for the intellectuals that gives floor to the representatives of very different, sometimes conflicting views. This concerns attitude to Russia as well - from pragmatic to hostile. The cartoons were printed each Friday and accompanied a satirical article on the events of the week. Unlike the other three newspapers, Neatkariga Rìta Avize presents rather abstract cartoons which seldom fit the needs of this study.

For the research all the cartoons in the aforementioned newspapers in March and May 2016 were studied. These two months were chosen because of the two dates vital for the Latvian-Russian relations: March 16th, the Remembrance Day of the Latvian Legionnaires with marches across the center of Riga, and May 9th, the Victory Day largely celebrated by the Russian-speaking population. These dates reflect and sharpen the deep cleavage in the Latvian society over the history of World War II: March 16th commemorates (and partially praises) the Latvians who fought on the side of Hitler and May 9th celebrates those who fought with the Soviet Army against the Nazis. Those who go on the marches on March 16th see Soviet soldiers as "occupants" and legionnaires of the Waffen SS as "true heroes" who fought for an independent Latvia. Those who come to the celebrations of the Victory Day view legionnaires as "traitors and murderers" and ardently oppose their glorification.

At the same time, the year 2016 is a typical year of the Latvian-Russian relations without any major accidents or turning points. The analysis was facilitated by the fact that the researcher lived in Latvia at that time and could grasp the sociopolitical context from the inside.

Out of all the cartoons those of a geopolitical character were looked for - that is depicting Latvia and other countries or international organizations and relations among them as well as international processes such as migration. Here we understand geopolitics as the study of the effects of geography on international politics (George, Devetak \& Percy, 2017, p. 522). The classification of geopolitical cartoons was carried out to facilitate discourse analysis: caricatures were coded, described and put in a table with the following elements singled out: code, topic, description, caption, geopolitical entities, characters and their attributes, associations and the cartoonist. 


\section{Results}

84 March issues of the four studied newspapers contained 74 cartoons, of which 23 were geopolitical. In 88 May issues there were 77 caricatures of which 15 were geopolitical. That gives us the proportion of $31 \%$ of geopolitical cartoons in March and around 19\% in May signaling that international news and topics are a common inspiration for cartoonists.

If we combine the numbers over two months, they are almost the same for three newspapers - Diena (13 geopolitical cartoons over two months), Dienas Bizness (13) and Latvijas Avize (12). In Neatkarīgā Rìta Avīze in March and May there was only one caricature fitting the design of the research.

Of all the countries Latvia was depicted and/or mentioned in captions most frequently - in 19 cases over two months. Cartoonists actively reflect on the place of Latvia in the world and its interaction with other geopolitical entities. Russia is on the second place by the number of references, which reflects its role as the most significant Other. The third is the European Union (10 mentions) that is also crucial to the Latvian self-reflection. Then go the United States and Greece (4 mentions each) - the latter was often mentioned in the context of the debt crisis. Turkey (3 mentions) was the main character in the cartoons about the migration crisis. The OECD, Britain and Estonia were mentioned two times each - the first in the context of the attempts of Latvia to become an OECD member, the second in the context of Brexit and the third in comparison with Latvia in the situations where Estonia had already done something and Latvia had not. Other geopolitical entities were mentioned only once: that was China, Japan, Germany, Poland, Sweden, Syria, Ukraine, Belgium, Macedonia, NATO and Arab countries.

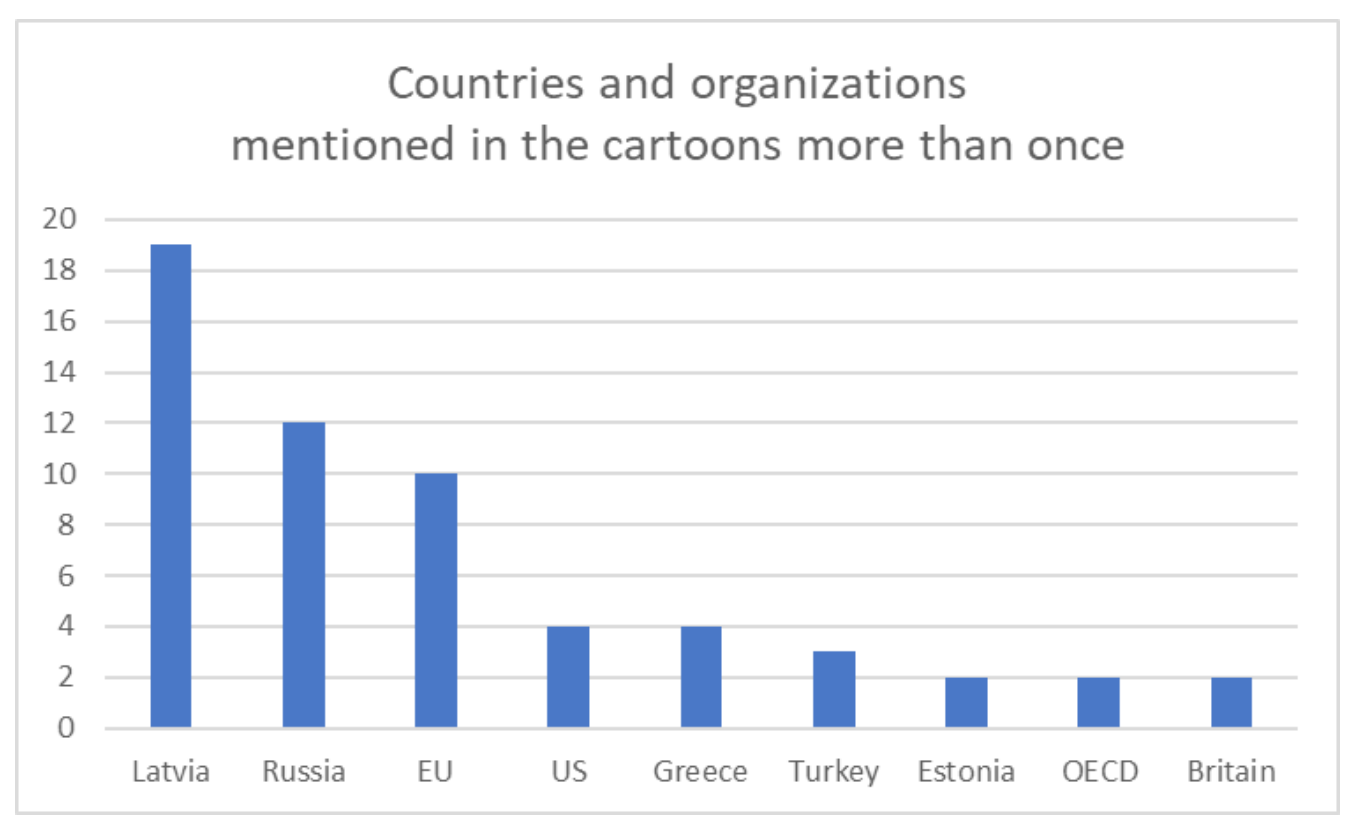

Table 1. Geopolitical entities mentioned in the cartoons of the Latvian newspapers in March and May 2016 more than once. 
The notion of Russia is transferred in many different ways. The simplest is just writing Russia on the cartoon or in its caption. Another obvious option is using the Russian flag and it is also widely employed. In case of the Victory Day the colours of the Georgian Ribbon are used. In a number of cartoons Russia is represented through individuals: president Vladimir Putin, ambassador in Latvia Alexander Veshnyakov and tennis-player Maria Sharapova. The Russian Bear is used only once over the studied period. A peculiar option is an ushanka (a traditional winter ear-flap hat) that helps identify a Russian - it is used in a cartoon by Agris Liepin,š about the disagreement among oil exporters published in Dienas Bizness on March 31st. In this picture a Russian in an ushanka and an Arab in traditional clothing fight over an oil pipe faucet. The Arab wants to close it, but the Russian does not let him, saying: "Every dollar is important for us!"

There are two main clusters of ideas associated with Russia in these cartoons. That is, firstly, lies, propaganda and the falsification of history. Secondly, that is power, threat and brutality.

For example, on May 9th Latvijas Avize published a cartoon by Gatis Šliuka with a syringe coloured as the Georgian Ribbon and a caption: "The inoculation of propaganda. Revaccination every May $9^{\text {th" }}$. The annotation notes that the Georgian Ribbon has become very popular among those celebrating the Victory Day in Riga despite the fact that these colours were an attribute of the Russian Imperial Army and did not have anything to do with World War II.

The second set of ideas - power, threat and brutality - can be illustrated by another cartoon by Gatis Šlūka published in Latvijas Avize on March 18th following the news of the withdrawal of the Russian troops from Syria. The caricature shows shirtless Vladimir Putin in military trousers carrying many army aircrafts in his arms and smiling maliciously. He steps out of a sandpit called Syria where a broken shovel lies. In the background there are more sandpits that, judging by the trace of footprints, Putin entered and left.

One can argue that cartoons are meant to be disrespectful. But in case of Russia the grade of negative emotions is usually much higher than with other entities. That is easily explained by tensions in the relations of the two countries and the need to distant from the antagonist Other that Russia has remained for Latvia. To prove a stronger prejudice against Russia we can compare the way Russia is depicted to the way Latvian cartoonists represent another significant Other the European Union.

The main association with the EU conveyed through the caricatures of the studied period is wealth and attractiveness. Following the rules of the genre many cartoons show negative sides of these seemingly positive traits. For example, a caricature by Gatis Buravcovs printed in Diena on May 27th reflects on the migration crisis. The picture shows numerous refugees crossing the fence between Turkey and the EU using ladders. The side of the EU is already crowded, a house named European Union is full. On the Turkish side there is a sign towards the EU 
border reading "Prosperity, allowance" and a barn from which the cries for help are heard. At the fence a woman resembling German Chancellor Angela Merkel (who in this case represents the EU leadership and not just Germany) tells a man in a fez resembling Recep Tayyip Erdoğan: "Ok, you may violate human rights, just put those ladders away". Here we still see the EU as (too) attractive, but the criticism is pointed against double standards and inability to stand up for oneself. The image is not as hostile as in case of Russia.

And how is Latvia viewed by the cartoonists? Main associations are poverty, weakness and ineptitude. A common topic is asking the EU for money. For example, a cartoon by Zemgus Zaharāns published in Diena on March 30th shows a rich gentleman representing EU with a blue tie holding a little dog called corruption on a golden leash (blue and yellow are the colours of the EU flag). The man (the EU) casts an annoyed look on another man in shabby grey clothes and a traditional Latvian hat representing Latvia. The latter asks the EU for money being almost completely devoured by a huge dog representing enormous corruption in Latvia.

Even on this basic level the contrast with the image of Russia is clear - Russia is powerful and aggressive; Latvia is feeble and harmless. But most strikingly this contrast is seen in the caricatures where both Russia and Latvia are presented.

One of the brightest examples is a cartoon by Ëriks Ošs printed in Latvijas Avize on May 13. Big figures of Russia's ambassador Veshnyakov and the Russian Bear hugging each other indignantly point at a tiny figure of a girl Latvia in traditional clothes. Veshnyakov cries: "She vilifies us! She scolds us!" The bear cries: "She wants to weaken us!" Little Latvia is silent. Here we see this antagonization at its maximum.

This and other such cartoons prove to the reader how different Russia and Latvia are and how real the Russian threat is. Almost in all caricatures Russia and Latvia are set against each other.

A seldom example where entities representing the two countries are on one side is a cartoon by Gatis Şlūka published by Latvijas Avize on March 11 devoted to the doping scandal with famous Russian tennis player Maria Sharapova who was caught using the Latvian drug Mildronate that had been put on the list of forbidden substances. In the picture a security guard with the caption WADA kicks out of the door of professional sport Maria Sharapova and a pack of Mildronate with a bruised eye. Sharapova asks why. The guard answers: "You came with it!" In this cartoon Sharapova and Mildronate suffer together, however, the link to the images of Russia and Latvia here is only indirect.

On the large scale one and the same narrative is repeated - week and a bit naive Latvia against strong and aggressive Russia.

\section{Conclusion}

What does the cartoon analysis tell us about the forging of the Latvian national identity? Latvia has succeeded in mentally distancing itself from Russia in many 
aspects, but the physical closeness remains and it fosters the antagonism with this significant Other. The result is numerous caricatures featuring Russia and its negative traits and reminding how different Latvia is. At the same time, Latvia still does not seem to see oneself as a fully integrated part of the Western world. Cartoons show how inapt and poor the country feels in comparison with its European partners and how they look down on it. Caricature reflects lack of national pride and skills to promote the country's goal.

The future of the research lies in enlarging the sample and refining on the methodology of the analysis.

\section{Acknowledgement}

The research has been funded by the Russian Science Foundation grant No. 19-78-10004 "Transformations of electoral behavior in the regions of foreign countries bordering on the Russian Federation: a comparative spatial analysis".

\section{References}

Abizadeh, A. (2005). Does Collective Identity Presuppose an Other? On the Alleged Incoherence of Global Solidarity. American Political Science Review, 99(1), 45-60. doi: 10.1017/ S0003055405051488

Alkazemi, M. F., \& Wanta, W. (2015). Kuwaiti political cartoons during the Arab Spring: Agenda setting and self-censorship. Journalism, 16(5), 630-653. doi: 10.1177/1464884914533072

Baratay, E. (2003). Le zoo, lieu politique, XVIe-XXe siècles [The Zoo, the Political Niveau, 19-20th centuries]. In P. Bacot (Ed.), L'animal en politique [The animal in politics] (pp. 15-36). Paris: L'Harmattan.

Berger, P. L., \& Luckmann, T. (1966). The Social Construction of Reality. A Treatise in the Sociology of Knowledge. London: Penguin Books.

Carter, M. J., \& Fuller, C. (2016). Symbols, meaning, and action: The past, present, and future of symbolic interactionism. Current Sociology, 64(6), 931-961. doi: 10.1177/0011392116638396

Demski, D., \& Baraniecka-Olszewska, K. (Eds.). (2010). Images of the Other in Ethnic Caricatures of Central and Eastern Europe. Warsaw: Institute of Archaeology and Ethnology, Polish Academy of Sciences.

Diena. (n.d.). Retrieved from https://www.diena.lv//

Dienas Bizness. (n.d.). Retrieved from https://www.db.lv/

Dugalich, N. M. (2020). Universal and Culturally Specific Features and Linguistic Peculiarities of the Political Cartoon in the Arabic and French Languages. RUDN Journal of Language Studies, Semiotics and Semantics, 11(3), 479-495. doi: 10.22363/2313-2299-2020-11-3-479-495

Eriksen, T. H. (1995). We and Us: Two Modes of Group Identification. Journal of Peace Research, 32(4), 427-436. doi: 10.1177/0022343395032004004

Gailìte, G. (2012a). Latviešu karikatūra XIX gs. Beigās XX gs. Sākumā kā nacionālās identitātes veidošanās un attīstības faktors (Latvian caricature as a factor of forming and developing 
national identity at the end of the 19th-The beginning of the 20th century). Letonica, (2), 2552. (In Latvian).

Gailite, G. (2013a). "Mother Latvia" in Constructing Self and Other: A Case of Latvian Caricature $19^{\text {th }}$ century (D. Demski, I. Sz. Kristóf, \& K. Baraniecka-Olszevwka, Eds.). Budapest: l'Harmattan.

Gailite, G. (2013b). The Bear and Latvia: images of Latvian-Russian relations in caricature. Labyrinth: the Journal of Socio-Humanitarian Studies , (4), 29-40. (In Russian).

Gamson, W. A., \& Stuart, D. (1992). Media Discourse as a Symbolic Contest: The Bomb in Political Cartoons. Sociological Forum, 7(1), 55-86. doi: 10.1007/BF01124756

George, J., Devetak, R., \& Percy, S. (2017). An Introduction to International Relations. Cambridge University Press.

Gurevitch, M., \& Levy, M. R. (1985). Mass Communication Review Yearbook (Vol. 5). Beverly Hills; London: Sage Publications.

Heidari-Shahreza, M. A. (2021). When a Nation Breathes Through Humor: A Sociolinguistic Perspective on Iranian Jokes About America. Society. doi: 10.1007/s12115-021-00608-5

Johnson, C., \& Coleman, A. (2012). The internal Other: Exploring the dialectical relationship between regional exclusion and the construction of national identity. Cultural and Humanitarian Geography, 1(2). Retrieved from https://gumgeo.ru/index.php/gumgeo/article/view/56 (In Russian).

Khrustalev, D. (2011). The Origin of the "Russian Bear". Novoje Literaturnoje obozrenie, (1), 137-152. (In Russian).

Koschut, S. (2018). The power of (emotion) words: On the importance of emotions for social constructivist discourse analysis in IR. Journal of International Relations and Development, 21(3), 495522. doi: 10.1057/s41268-017-0086-0

Latvia and Russia sign final documents on the demarcation of the border. (2017, Ocrober 25). Retrieved from TASS website: https://tass.ru/mezhdunarodnaya-panorama/4676634 (In Russian).

Latvijas Avīze. (n.d.). Retrieved 18 September 2021, from LA.LV website: https://www.la.lv/

Mead, G. H. (1965). Mind, Self and Society. Chicago; London: University of Chicago Press.

Moloney, G., Holtz, P., \& Wagner, W. (2013). Editorial Political Cartoons in Australia: Social Representations \& and the Visual Depiction of Essentialism. Integrative Psychological and Behavioral Science, 47(2), 284-298. doi: 10.1007/s12124-013-9236-0

Neatkarīgā Rīta Avīze. (n.d.). Retrieved 18 September 2021, from https://nra.lv/

Popkov, V. D. (2002). Stereotypes and Prejudice: their Impact on Interculture Communication. Journal of Sociology and Social Antropology, 5(3), 178-191. (In Russian).

Procevska, O. (2011). The Bear, the Eagle, and the Hair Hand: Metaphorization of Russia in Latvian Press. In I. Novikova (Ed.), Europe - Russia: Contexts, Discourses, Images (pp. 177-187). Riga: LU DZSC - LEVIRA.

Salamanca, D. G., \& Rodrigues, J. R. (2015). The Drama of Caricature: Simplification and Deformation as Avant-Garde Rhetorical Devices. In E. Claudio \& J. Cañero (Eds.), On the edge of the panel essays on comics criticism (pp. 94-108). Cambridge: Cambridge Scholars Publishing.

Schmitt, C. (1996). The Concept of the Political. Chicago: University of Chicago Press.

Tavory, I. (2014). The situations of culture: Humor and the limits of measurability. Theory and Society, 43(3-4), 275-289. doi: 10.1007/s11186-014-9222-7 
Troitskiy, S. (2020). The Imagological Bestiary in the Political Caricature at the turn of the 19th $20^{\text {th }}$ centuries, 1890-1905: Zoophisiognomy as the Instrument of Visual Rhetoric. Doxa, (1), 159174. doi: 10.18524/2410-2601.2020.1(33).211981 (In Russian).

\section{Список литературы}

Abizadeh, A. (2005). Does Collective Identity Presuppose an Other? On the Alleged Incoherence of Global Solidarity. American Political Science Review, 99(1), 45-60. doi: 10.1017/ S0003055405051488

Alkazemi, M. F., \& Wanta, W. (2015). Kuwaiti political cartoons during the Arab Spring: Agenda setting and self-censorship. Journalism, 16(5), 630-653. doi: 10.1177/1464884914533072

Baratay, E. (2003). Le zoo, lieu politique, XVIe-XXe siècles [The Zoo, the Political Niveau, 19-20th centuries]. In P. Bacot (Ed.), L'animal en politique [The animal in politics] (pp. 15-36). Paris: L'Harmattan.

Berger, P. L., \& Luckmann, T. (1966). The Social Construction of Reality. A Treatise in the Sociology of Knowledge. London: Penguin Books.

Carter, M. J., \& Fuller, C. (2016). Symbols, meaning, and action: The past, present, and future of symbolic interactionism. Current Sociology, 64(6), 931-961. doi: 10.1177/0011392116638396

Demski, D., \& Baraniecka-Olszewska, K. (Eds.). (2010). Images of the Other in Ethnic Caricatures of Central and Eastern Europe. Warsaw: Institute of Archaeology and Ethnology, Polish Academy of Sciences.

Diena. (n.d.). Retrieved from https://www.diena.lv//

Dienas Bizness. (n.d.). Retrieved from https://www.db.lv/

Dugalich, N. M. (2020). Universal and Culturally Specific Features and Linguistic Peculiarities of the Political Cartoon in the Arabic and French Languages. RUDN Journal of Language Studies, Semiotics and Semantics, 11(3), 479-495. doi: 10.22363/2313-2299-2020-11-3-479-495

Eriksen, T. H. (1995). We and Us: Two Modes of Group Identification. Journal of Peace Research, 32(4), 427-436. doi: 10.1177/0022343395032004004

Gailìte, G. (2012). Latviešu karikatūra XIX gs. Beigās XX gs. Sākumā kā nacionālās identitātes veidošanās un attīstības faktors (Latvian caricature as a factor of forming and developing national identity at the end of the 19th-The beginning of the 20th century). Letonica, (2), 2552. (In Latvian).

Gailite, G. (2013). "Mother Latvia" in Constructing Self and Other: A Case of Latvian Caricature $19^{\text {th }}$ century (D. Demski, I. Sz. Kristóf, \& K. Baraniecka-Olszevwka, Eds.). Budapest: l'Harmattan.

Gamson, W. A., \& Stuart, D. (1992). Media Discourse as a Symbolic Contest: The Bomb in Political Cartoons. Sociological Forum, 7(1), 55-86. doi: 10.1007/BF01124756

George, J., Devetak, R., \& Percy, S. (2017). An Introduction to International Relations. Cambridge University Press.

Gurevitch, M., \& Levy, M. R. (1985). Mass Communication Review Yearbook (Vol. 5). Beverly Hills; London: Sage Publications.

Heidari-Shahreza, M. A. (2021). When a Nation Breathes Through Humor: A Sociolinguistic Perspective on Iranian Jokes About America. Society. doi: 10.1007/s12115-021-00608-5 
Koschut, S. (2018). The power of (emotion) words: On the importance of emotions for social constructivist discourse analysis in IR. Journal of International Relations and Development, 21(3), 495522. doi: 10.1057/s41268-017-0086-0

Latvijas Avize. (n.d.). Retrieved 18 September 2021, from LA.LV website: https://www.la.lv/

Mead, G. H. (1965). Mind, Self and Society. Chicago; London: University of Chicago Press.

Moloney, G., Holtz, P., \& Wagner, W. (2013). Editorial Political Cartoons in Australia: Social Representations \& and the Visual Depiction of Essentialism. Integrative Psychological and Behavioral Science, 47(2), 284-298. doi: 10.1007/s12124-013-9236-0

Neatkarīgā Rīta Avīze. (n.d.). Retrieved 18 September 2021, from https://nra.lv/

Procevska, O. (2011). The Bear, the Eagle, and the Hair Hand: Metaphorization of Russia in Latvian Press. In I. Novikova (Ed.), Europe - Russia: Contexts, Discourses, Images (pp. 177-187). Riga: LU DZSC - LEVIRA.

Salamanca, D. G., \& Rodrigues, J. R. (2015). The Drama of Caricature: Simplification and Deformation as Avant-Garde Rhetorical Devices. In E. Claudio \& J. Cañero (Eds.), On the edge of the panel essays on comics criticism (pp. 94-108). Cambridge: Cambridge Scholars Publishing.

Schmitt, C. (1996). The Concept of the Political. Chicago: University of Chicago Press.

Tavory, I. (2014). The situations of culture: Humor and the limits of measurability. Theory and Society, 43(3-4), 275-289. doi: 10.1007/s11186-014-9222-7

Гайлите, Г. (2013). Медведь и Латвия: Образы латышско-российских отношений в карикатуре. Лабиринт: журнал сощиально-гуманитарных исследований, (4), 29-40.

Джонсон, К., \& Коулман, А. (2012). Внутренний «Другой»: Диалектические взаимосвязи между конструированием региональных и национальных идентичностей. Культурная и гуманитарная география, 1(2). Извлечено от https://gumgeo.ru/index.php/gumgeo/article/view/56

Латвия и Россия подписали итоговые документы по демаркации границы. (2017, октябрь 25). Извлечено от ТACC website: https://tass.ru/mezhdunarodnaya-panorama/4676634

Попков, В. Д. (2002). Стереотипы и предрассудки: Их влияние на процесс межкультурной коммуникации. Журнал сощиологии и социальной антропологии, 5(3), 178-191.

Троицкий, С. (2020). Имагологический бестиарий в политической карикатуре на стыке XIX-XX веков (1890-1905): Зоофизиогномика как инструмент визуальной риторики. Doxa, (1), 159-174. doi: 10.18524/2410-2601.2020.1(33).211981

Хрусталев, Д. (2011). Происхождение «русского медведя». Новое литературное обозрение, (1), $137-152$. 